\title{
The Convention to Combat Desertification and the Role of Innovative Policy-Making Discourses: The Case of Burkina Faso
}

Hans Bruyninckx

The United Nations Convention to Combat Desertification (from now on referred to as the Desertification Convention or abbreviated as CCD) was adopted in 1994 and entered into force in December 1996. Its aim is to combat desertification, i.e. soil degradation, ${ }^{1}$ in a number of specified regions. ${ }^{2}$ To date (2004), 191 countries are members to the convention. In order to achieve its aim, the CCD uses the traditional institutional arrangements, instruments and mechanisms, which we find in many international agreements and regimes. ${ }^{3}$ After several years of negotiations, states set up an international institutional framework, including a decision-making body, the Conference of the Parties (COP), a permanent regime secretariat, and a number of committees, which follow-up the activities and prepare future COPs. In addition, a compliance and sanctioning mechanism is specified. A Committee on Science and Technology ensures also a serious input from scientists in the operation of the regime. ${ }^{4}$

Typical for the functioning of international environmental regimes and policy-making is also that the goals and principles included in the CCD are determined at the level of the COP and then translated into practice at the national policy level (National Action Plans in the case of the CCD) and, specifically for the CCD also at the regional level (Regional Action Plans). This regional level forms a key strategic planning and operational level for the convention. The regional emphasis is elaborated in four regional annexes to the

1. The CCD defines desertification as "land degradation in arid, semi-arid and dry sub-humid areas resulting from various factors, including climatic variations and human activities" (UNCCD 1994, Article 1).

2. It is important to point out the convention is not aiming to fight desertification on a global scale. There is a clear regional approach aiming at-in general-developing regions. The problems of soil degradation in France and the Mid West of the USA for example do not fall under the convention.

3. Cf: Caldwell 1990; Hurrell and Kingsbury 1992; Haas et al. 1993; and Young 2000

4. Chasek and Corell 2002

Global Environmental Politics 4:3, August 2004

๑ 2004 by the Massachusetts Institute of Technology 
CCD, which outline implementation trajectories that are adapted to the regional contexts and in line with the political choices that have been made during the negotiations. It is obvious from the text that Africa as a continent received most attention, ${ }^{5}$ followed by Asia, Latin America and the Caribbean and the Northern Mediterranean.

Based on the above, the Desertification Convention can be described very much as a "normal, standard" regime. However, in addition to this fairly straightforward institutional set-up, the Desertification Convention also makes ample use of the newer international policy discourses of participatory policymaking and implementation, decentralization as a fundamental policy goal, and the use of local knowledge as an explicit "good." The sustainable development concept forms the overarching umbrella for these discourses, which represent-at least in policy practices-a fairly recent dimension in international environmental policy-making. In fact, the CCD could be considered as the first of a new generation of post-Rio regimes, which could be labeled "sustainable development regimes." ${ }^{\prime \prime}$ Not only is the Desertification Convention setting norms and standards for the behavior of states; it also encourages states to reach certain goals, through constitutional and other reforms (i.e. decentralization of state power), and/or through the implementation of a different view of state-society relations (i.e. participatory policy-making at decentralized policy levels). The inclusion of these elements in the CCD has its impact on how signatory states try to comply with the regime's requirements. In addition, this normative framework also adds an important challenge to the task of evaluating the performance of actors, and the regime as a whole.

In this article I will discuss these innovative-and often explicitly normative-policy elements in more detail, and describe how they play out in a concrete policy reality in West Africa. The case study is based on field research done in Burkina Faso, and more specifically in the Yatenga province and the city of Ouahigouya. ${ }^{7}$ The case study will illustrate how Burkina Faso has attempted to implement the CCD and also analyze the differences between policy discourses and realities. It will become clear that significant discrepancies exist between regime intentions and local implementation in the specific context of developing countries. I will end with some tentative conclusions on the impact of the sustainability discourse that permeates the CCD, on its functioning, and on the expectations that are created by the use of these discourses.

5. The Desertification Convention has also been labeled the "African convention." During the negotiations in preparation of the UNCED conference in Rio 1992, much pressure was necessary to maneuver this convention through the process. African countries in particular used much of their bargaining power to reach this result. For a further account of the negotiations and the different positions I refer to Corell 1999.

6. Chasek 1997; and Corell 1999.

7. Since 1997, the Research Group on Sustainable Development of the HIVA research institute, Catholic University Leuven, has made multiple research trips to Burkina Faso and the Yatenga region. This research was funded by the following grant institutions: the Flemish Interuniversity Council (VIIR), the STEP-BIT program of the ILO, and UNDP. 


\section{The Policy Discourses of the Desertification Convention}

The Desertification Convention is, as mentioned above, a mix of conventional or traditional elements, which can be found in most international environmental agreements, and a set of innovative elements. These innovative elements can be interpreted as emanations of policy discourses, which have been gaining in importance since the introduction and the fairly broad acceptance of sustainable development and Agenda 21 as guiding conceptual frameworks for international environmental and development initiatives. In Article 9 of the Desertification Convention the link with sustainable development is made explicitly. It states that the National Action Programs should "be closely interlinked to formulate national policies for sustainable development" (Article 9 [1]). In the convention this new policy discourse is further translated into other, more specific articles, including obligations and recommendations for signatory states.

I will take a closer look at three specific discourses, namely, the participation discourse, the decentralization discourse, and the local knowledge discourse. Each one is strongly represented in the convention and has, at least in theory, significant impact on the policy dynamics in the signatory states. ${ }^{8}$

\section{a. The Participation Discourse}

Sustainable development is often described as the integration of social, economic and environmental objectives. ${ }^{9}$ One could add the participatory dimension as the fourth objective. Agenda 21 devotes considerable attention to the participatory aspects, both in an instrumental and in a more fundamental or normative way. ${ }^{10}$ From an instrumental perspective, participation is often described as being useful, because it makes the implementation of policies more acceptable and hence easier. From a normative perspective, a more participatory society is deemed "better" than one with less input from citizens and groups, because of its higher democratic and representative nature. The "stakeholder approach," and the policy processes associated with it, bring these two elements together: stakeholder involvement in policy-making is believed to lead to empowerment as a positive outcome and better policy-making in both planning and implementation stages. ${ }^{11}$

8. The CCD also includes a number of other innovations which I will not discuss at length in this article. These include: linkages between sectoral and cross-sectoral policies, stronger partnerships between North and South through differential membership status and financing mechanisms, emphasis on NGOs as valid and central actors in processes, and so on. For further discussion see Corell 1999; Chasek 1997; Sokona et al. 2000; and the many documents on the website of the convention.

9. World Commission on Environment and Development 1987.

10. Bachus and Bruyninckx 2001.

11. Hemmati 2002; and Corell 1999. This type of reasoning is spreading out into other international policy-making efforts as well; the CCD is clearly not an isolated case. A good example is 
The CCD clearly opts for a "bottom-up" approach along these lines. In fact, some consider this to be the most defining or even unique element of the convention. ${ }^{12}$ In the Desertification Convention we find the participatory policy-making discourse in a number of specific articles:

- Article 9 (1), which outlines the basic approach to the action programs, spells out that they should be the outcome of a "participatory process on the basis of lessons from field action."

- Article 10 (2) (f) calls for "effective participation at the local, national, regional level of non-governmental organizations and local populations ... in policy planning and implementation and review of NAPs."

- Article 13 (1) further develops this point of view by calling for "participatory action at the community level" in the elaboration and implementation of programs.

It is obvious from the convention texts that "participation" should be understood as a policy process, which includes local populations, NGOs, and decentralized institutions as involved partners in addressing policy problems. Moreover, the emphasis on participatory and bottom-up approaches is a reflection of, and is reflected in, the significant role of NGOs during the negotiations of the CCD, and their role in the implementation phase. ${ }^{13}$ Normative elements connected to the empowerment discourse are implicit rather than explicit in the basic convention text. However, in subsequent documents prepared for COPs and other convention related meetings the participatory aspects and the empowerment discourse are further elaborated.

\section{b. The Decentralization Discourse}

It is rather unusual for international (environmental) regimes to call for fundamental changes in the distribution of political, institutional and policy responsibilities within signatory states. In a way, the Desertification Convention does just that. There is an explicit and rather strong undertone of decentralization in the convention text and also in the subsequent reports and plans. This discourse suggests that decentralized policy-making and implementation has a better chance of reaching the goals of the convention than the fairly centralized, command-and-control style of policy-making, which is dominant in many developing countries. ${ }^{14}$ The reasons might be that local governments: have a better feeling for the "real" problems; are better at prioritizing based on more adapted, and hence more relevant, knowledge of the local situation; and are better equipped to allow for stronger inputs from civil society, through participatory processes. The rationale is of high relevance for the $\mathrm{CCD}$, because of the nature

\footnotetext{
the EU integrated water management directive, which requires member states to change towards more participatory forms of integral water management. 12. Corell 1999, 90.

13. Corell and Betsill 2001.

14. Grindle and Thomas 1991; and Long 2001.
} 
of the processes of desertification. Soil degradation often has strong and specific local impacts on farmers and other groups. In terms of concrete policy measures, the local level is therefore important because these measures tend to be based on actions that are implemented at the level of the individual farmer and/ or locally embedded organizations. ${ }^{15}$

The text of the convention, however, implicitly suggests an even stronger argument for decentralization. It reflects the general idea that decentralization in developing countries will provide a more fertile ground for more participatory and more effective policy-making, through the spreading of a more democratic political context. This same discourse can be found in documents and policy programs conducted by the World Bank and the International Monetary Fund. It is often (partially) translated as good governance in the conditions for financial support and loans. ${ }^{16}$

In the Desertification Convention we find this type of reasoning in Annex I on the Regional Implementation for Africa:

- Article 4 (2) (b): African countries should "sustain and strengthen reforms currently in progress towards greater decentralization"

- Article 8 (3) (c): under the measures to be taken to improve institutional organization we find the following obligations/recommendations: "defining the roles and responsibilities of central government and local authority in the framework of land use planning policy" and "encourage a policy of active decentralization, devolving responsibility ... . for decisionmaking to local authorities ... and the establishment of local structures"

These are very far-reaching recommendations/obligations. The decentralization of state power in terms of institutional arrangements and policy-making capacity and responsibilities is a fundamental political decision in any country. ${ }^{17}$ To request this under an international regime and in an African context is very unusual and its implementation requires the combination of a number of complex political, bureaucratic and policy processes.

\section{c. The Local Knowledge Discourse}

The knowledge base for most international agreements comes from traditional, that is Western, modernist, peer reviewed, scientific knowledge. ${ }^{18}$ Each regime

15. Donnely-Roark et al. 2001.

16. An example is Mali, a country that has implemented a decentralization of its political and policy-making system through locally elected municipal authorities. This whole process was, however, clearly donor-driven (Inspectie Ontwikkelingssamenwerking en Beleidsevaluatie 2001). I also wish to make it clear that the IMF and World Bank concepts of good governance entail other elements that are for most observers not in the "spirit" of the CCD. The suggestion that decentralization processes are also supported (if not demanded) by these institutions does not imply any positive link between their overall policy recommendations and the fight against desertification.

17. Migdal et al. 1994 .

18. Haas 1992; Litfin 1994; and Corell 1999. 
has its specific way of introducing science and scientists into the political and policy cycle. Scientists can be organized in a sort of "in house" arrangement, or through the specific use of knowledge, coming from certain well-defined groups or networks of scientists. Other regimes are less specific in where they get the scientific underpinnings, but overall, the knowledge base can be found in traditional scientific research, based on the principles of academic/scientific research.

However, in line with the Agenda 21 discourse, the CCD emphasizes local or traditional knowledge, as a basis for planning and policy-making. The idea is that local groups including farmers, women, foresters and others-have a strong "common sense" and experience-based knowledge of the dynamics of desertification. Moreover, they are supposed to be exceptionally well placed to make linkages between agricultural or pastoral practices, local social dynamics and the process of soil degradation. This knowledge is until now hardly inventoried, analyzed or put to use for policy-making. If this were done more frequently and systematically, there would be, according to the proponents of this view, several beneficial effects on the policy process. One argument is that policies would be based on a much broader and pragmatic knowledge base, thus increasing the chances of arriving at the best possible solutions. Moreover, solutions to problems would be much better integrated with the existing practices of local stakeholders and hence adapted to local implementation realities. Finally, the support base for the policies, or the acceptability of solutions, would be stronger, due to both the involvement of locals via their cognitive input, and also because they have been part of the process. This surplus value embedded in the process itself is called the "additionality argument." There is another aspect to this argument: the inclusion of local knowledge is frequently mentioned because it conforms to the normative discourse of involving and recognizing marginalized groups and indigenous peoples.

In the Desertification Convention we find this reasoning in section 2 on scientific and technical cooperation.

- Article 16 (g): calls for the use of "traditional knowledge, ensuring adequate protection for it and providing appropriate space for the benefits derived from it, on an equitable basis and on mutually agreed terms"

- Article 17 (1) (c): countries should "protect, integrate enhance and validate traditional and local knowledge ... [in such a way that] will directly benefit on an equitable basis and on mutually agreed terms [those involved]"

- Article 17 (1) (f): calls for "affordable and accessible technologies for sustainable development through the participation of local populations and communities"

- Article 18 (2): countries should "make inventories of such technology, knowledge, know-how and practices" and ensure that "local populations benefit directly." 
The inclusion of local or traditional knowledge does not happen spontaneously. The literature describing the role of this type of knowledge in policy processes emphasizes specific methodologies to make the process work. ${ }^{19}$ In addition, the normative bias towards local knowledge-as good and authenticversus scientific knowledge-as distant and culturally unadapted-is an element that should be taken into account when analyzing the implementation of this type of discourse.

In summary, the Desertification Convention has put a strong emphasis on a number of more innovative elements, which we find back in more recent regimes, especially those including developing countries. ${ }^{20}$ They are part of a more integrated approach towards policy-making and implementation. In that sense, the three discourses are intertwined and to be considered as a whole. It can be argued that participation at decentralized levels of policy-making, based on the use of local knowledge and in support of empowering local communities, is or can be considered the "message" embedded in the CCD.

These policy discourses are representative of a number of institutional arrangements connected to the sustainable development policy framework, as it has been explained in Agenda 21, and further elaborated by the United Nations Commission for Sustainable Development, the United Nations Environmental Programme, and other international institutions, which provide the overarching conceptual architecture for more recent international environmental conventions. The third part of this article uses a case study from Burkina Faso to show how the convention's sustainable development framework prescribes roles for different policy-making levels and actors from a bottom-up perspective.

\section{Case Study: Burkina Faso}

\section{a. Background}

Burkina Faso is a relatively small, land-locked West African country with a population of about 10.5 million people. It is poor in natural resources and scores extremely low on nearly all development indicators, whether they are economic, social, or environmental. It ranks 172nd on the Human Development Index, which puts it in the group of Least Developed Countries and makes it comparable to Niger, Ethiopia and Sierra Leone. The average GNP per capita is about $\$ 230$ US per year. Despite its unfavorable natural conditions, however, $85 \%$ of the population's economic activity and about $70 \%$ of the exports of the country come from agricultural activity. These activities take place under bad conditions of an increasing impact from climatological changes, degradation of

19. Long 2001.

20. Other examples include the Biodiversity Convention and a number of international agreements on, for example, Local Agenda 21. 
natural resources, demographic growth of nearly $3 \%$ per year, anarchical use of the open space, un-adapted methods of cultivation, and so on. ${ }^{21}$

A further complication is the internal migration issue. Between 1985 and 1991, about $10 \%$ of the total population was affected, either because of their own decision, in search of better living and working conditions, or as a part of a government policy of relocation of populations to better agricultural zones. The ironic part is that migratory movements are largely triggered by conditions of desertification, but because of how they take place, are themselves cause for further natural resource degradation. ${ }^{22}$ Indeed, lack of planning of impact assessments and of follow-up have led to mostly unsuccessful migration dynamics inside of the country.

The political conditions in the country can be summarized by mentioning that no president or political leader has been elected to power in the last three decades (although some have been confirmed once they were in office). After a period of self-sufficiency under president Sankara, a military coup has brought a fairly small group of (ex) military leaders into power under the leadership of Blaise Compaoré. The current regime can be described as "authoritarianismlight," and compared to other regimes in the region it is considered to be fairly stable. Even so, freedom of the press is constantly in danger, government institutions are characterized by widespread corruption, and in general, there is a lack of a well-functioning central state. ${ }^{23}$

In conclusion, the situation in Burkina Faso is one of severe poverty, serious soil degradation, marginal economic conditions and a political context that is, at first sight, not exactly "fertile ground" for the implementation of the policy discourses in the Desertification Convention that refer to issues such as more democratic policy-making, stakeholder management, and decentralization. In the following section I will take a more detailed look at how, despite this context, the government of Burkina Faso has attempted to draft a National Action Plan that reflects the goals set in the CCD convention texts.

\section{b. The National Action Program to Fight Desertification}

In order to fulfill its obligations under the Desertification Convention, the Burkinabé government has submitted a national action program to the CCD secretariat. The NAP is, besides being a formal CCD requirement, also consid-

21. Burkina Faso Government 1999, 11. Anarchical methods of the use of open space are often connected to very local traditional methods of land ownership and use. Although they can be historically and socially functional, they are becoming increasingly environmentally harmful under the current demographic and climatological conditions.

22. Burkina Faso Government 1999.

23. I come to this conclusion based on several long-term research projects that have been carried out by the research group on sustainable development of the Catholic University Leuven. These have included healthcare, poverty eradication and economic development. The overall conclusion is the relative weakness of the central state to deal with problems (cf. Defourny et al. 1999; Fonteneau 2000; and Valkenborg 2000). 
ered to be crucial for the further general development of the country as "all efforts toward development are jeopardized by the effects of the drought and the desertification of which the country has fallen victim for the last decades, and which puts a heavy burden on the scarce natural resources of the country."24

Reoccurring droughts of varying severity and desertification have substantial impact on all aspects of Burkina Faso's socio-economic functioning. ${ }^{25}$ First, and foremost, is the fact that during periods of drought, the level of food production is reduced and under pressure because of topsoil degradation and erosion. ${ }^{26}$ Secondly, drought and desertification have an impact on the abundance of all sorts of natural products that are gathered and used in daily subsistence activities. This aspect is especially important to women and children who are the key actors here. In general, the desertification process is responsible for a further impoverishment of animal and plant species, leading to a "vicious cycle" of desertification and human impoverishment. The most serious immediate consequence is the further stress on overall food-security. Malnutrition and poor health are the most visible outcomes. ${ }^{27}$

The government emphasizes the importance of the National Action Plan by offering two possible scenarios for the country's future. ${ }^{28}$ The pessimistic scenario could be labeled BAU (business as usual) and predicts further desertification, less food security, more migration, and so on. The optimistic scenario, which could (or should) be a consequence of the implementation of the NAP, as part of a broader national strategy for sustainable development, is based on the belief that a number of trends can be reversed. The outcome of this strategy will depend to a large extend, according to the NAP, on partnerships between the national government and local actors, primarily the farmers.

It is important to place the NAP (as a part of CCD implementation efforts) in a historic trajectory of planning efforts in Burkina Faso. Indeed, the NAP can be considered as the next step in a 20-year history of different "national development plans" in Burkina Faso. These quintannual or triannual development plans have generally included elements specifically aimed at protecting the natural resources of the country. In that sense, the linking of development to environmental issues is certainly not something completely new. Examples of policy plans including such fundamental linkages are the Plan National de Lutte

24. Burkina Faso Government 1999, 15. More recently, the deserts in the Southern part of the Sahara are said to be retreating, especially in West Africa. In this article I will not comment on the correctness of this information, nor discuss the possibility of a causal link between the Burkinabé policies and the process of desert formation or retreat. Those issues have only marginal relevance for the points I am trying to make.

25. Donnely-Roark et al. 2001.

26. It is important to point out that the problem of food production is to a large extent linked to periods of relative drought (or other pests). In fact, recent research suggests that the average food production per capita in Burkina Faso has increased over the last two decades (Pearce 2001). This doesn't mean, however, that there are no problems with the (social) distribution of food or with malnutrition.

27. Donnely-Roark 2001; and Fonteneau 2000.

28. Burkina Faso Government 1999, 30. 
contre la Désertification (PNLCD, 1986) and the 1991 Plan d'Action National pour l'Environnement (PANE), and the Plan d'Action Forestier Tropical (PAFT, 1991). All these plans have been characterized by rather poor institutional support and, in general, equally poor implementation. The National Action Programme attempts to deal with these issues by framing it in a number of institutional changes that dovetail with the innovative discourses described above: decentralization, more participatory institutional arrangements and policymaking processes, and, in addition, a number of legislative initiatives which give more teeth to the national environmental administration (Ministère chargé de l'Environnement).

The National Action Plan under the Desertification Convention meets all the formal requirements of the convention and describes policy options for all the relevant issues. However, in order to implement the NAP, several elements are of crucial importance for a country such as Burkina Faso. A fundamental precondition is the existence of a political context that allows societal actors and stakeholders to discuss the issues and the dynamics at stake. In addition, the political system has to maintain good channels for the distribution of relevant and sufficient information and communication flows. The inclusion of a process of decentralization and the operationalization of stakeholder management in countries with authoritarian regimes such as Burkina Faso are for that reason, in fact, far from self-evident. The fact that the majority of the population of Burkina Faso is illiterate doesn't facilitate this element either. Another important precondition is the existence of an institutional policy-making context with the capacity to deal with the issue at stake. ${ }^{29}$ Given the general weakness of (West) African states this is a seriously limiting contextual variable. The institutional set-up and the endogenous capacity at the different policy levels is generally weak or absent. Moreover, the participatory discourse presupposes either a civil society that is organized enough and has the capacity to be a competent actor in these sorts of processes, or specific methods for including deprived, illiterate and marginalized groups. ${ }^{30}$

When the NAP is analyzed through a more critical, policy implementation, lens, it can be described as a fairly vague and repetitive document. It contains almost no strategic or operationalizable goals, no specific actions, no timing, and little or no estimate of the capacity and means necessary for implementation. In general, there is a fairly large discrepancy between the demands put on a polity to implement certain policy dynamics, which are included in the CCD, and the actual policy context in countries such as Burkina Faso. This may (partially) explain the fact that domestic actors have become increasingly dependent on outsiders to intervene in policy planning and implementation. The natural resource policies of Burkina Faso are an example of this dynamic. They have been executed to a large extent through the intervention of 
ODA agencies and foreign NGOs. This seems at odds with the policy dynamics suggested in the Desertification Convention. The NAP also explains the financial mechanisms associated to the plan in rather vague terms, but points out that "the majority of the actions in the combat against desertification are actually financed . . . by external sources under bilateral and multilateral programs." 31 The transfer of these and other funds to the level of towns, villages and farmers should happen through "development funds" and "local credit organizations" (NAP).

In the preface to the plan, the Burkinabé government implicitly answers these concerns by developing the most important challenges for the next 10 years: decentralization of decision-making power, creating (!) local governments, and promoting a process of general democratization of society. This type of change is necessary given "the important role of bad policies and bad development [dynamics]"32 that have been major causes of desertification and obstacles to the participation of interested groups in civil society.

In line with the Desertification Convention texts, the Burkinabé NAP contains several specific policies aimed at introducing or strengthening the more innovative, sustainable development elements of the convention. In the following paragraphs, I will link the intentions of the NAP to implementation in the country.

i. Decentralization Discourse and Policy: The new constitution of June 1991 created both new decentralized political entities, and a (marginal) administrative decentralization of governmental services in Burkina Faso. The first municipal elections took place in February 1995, in 33 municipalities. In April 1996 an institutional decentralization took place through the founding of 15 new provinces and 22 departments. ${ }^{33}$ Finally-and strangely enough several years after the elections-in August 1998 the parliament enacted the "texte d'orientation sur la décentralisation." This law outlines the precise implications of the decentralization process in terms of the distribution of power and responsibilities.

In general, decentralization in Burkina has "been well received because of the seriousness and caution that have been invested in the process, the results from serious efforts and careful investigation by the National Decentralization Commission (Commission Nationale de Décentralization)." ${ }^{\prime 34}$

The results of the changes are on the one hand a country with "collectivités locales" or local authorities, and on the other hand "circonscriptions administratives" or lower administrative districts. The decentralization reinforces the right of the local authorities to take autonomous policy decisions on a limited number of policy issues, including certain elements of natural resource management. However, in order to strengthen the opportunities and

31. Burkina Faso Government 1999, 44.

32. Burkina Faso Government 1999, 10.

33. Ministère de l'environnement et de l'eau 1999.

34. IDEA 1998, 53. 
capacity for action of the local authorities, the process of decentralization would have to be accompanied by a process of adequate deconcentration of state services. ${ }^{35}$ Although on paper things have changed in that direction, so far little actual change can be observed "en brousse" (on the ground).

ii. Participatory Discourse: The NAP mentions that, after decades of "productiviste" and "sectoral" approaches to natural resource management, it is now time for a "decade of participatory development," or rather, a "retour" (a "return") to the participation of populations in development activities. This will require the promotion and "elevation of the conscience" of those involved and a "spirit of initiative." The "return" idea is important because Burkina Faso has a fairly long tradition of participatory policy-making at the most decentralized levels. Local institutions, whether formal or informal, have long played a crucial role in the social practices that have been in place in natural resource management, agriculture and other crucial areas of social organization. ${ }^{36}$

This view is further developed in the NAP by its mentioning of the effective participation of populations in the planning process, and the need to outline a system for more effective rights of local populations over natural resources. In addition, the NAP clearly states the need for further devolution of policy-making competencies and financial responsibilities.

The participatory discourse is further operationalized by the establishment of several commissions and committees, that are involved in the policy process on natural resources issues: (1) the COPOD (Comite de Pilotage des ONG sur la désertification) is the consultation and advisory committee of the NGOs, which are involved in the fight against desertification; (2) the Coordination of the Actions of Development Partners (National Official Development Aid agencies) which has to create synergies between all those involved; (3) and, last but not least, the CCOF, which is the Consultation framework for farmers' organizations -almost 15000 local and regional organizations reunited in three large organizations- which will be involved in the development of the national plans. ${ }^{37}$

For the broader National Sustainable Development Policy the CONAGESE (national council for environmental management) has been created. It has (according to the government) members from all relevant national groups, including scientists. In line with the recommendations of the CCD, the CONAGESE organized a national process of participatory planning and information during the 1997-1999 period. The goal was to come up with a new, grass-roots driven national plan to fight desertification. The process received support from the UNDP and eight other donors, which can be interpreted as an illustration of the limited internal capacity, and hence the need for significant exogenous institu-

35. Savadogo $1998,7$.

36. Donnely-Roark et al. 2001; Boissard 1996; and Valkenborg 2000.

37. Ministère de l'environnement et de l'eau 2002. 
tional involvement. The process consisted of what has been labeled a "capacity building pyramid."

This vast pyramid of committees functions as a cascade of capacity building, information sharing, awareness raising and empowerment of all stakeholders-focusing especially on the strengthening of capacities for planning and management at the village level. The national committee trains the regional committees, which train the provincial committees, which train the departmental committees, which train the village committees. Village steering committees consist of between five and 10 people, one of whom must be literate in order to act as secretary. These committees constitute the nucleus of the system of local governance and local action plans on which the country's anti-desertification strategy is based..$^{38}$

A total number of about 47,000 people were involved as the nucleus of the exercise, with several hundred thousand attending meetings at the various levels (primarily at the village level). The process also relied heavily on existing networks of farmers, and women's and other groups, to organize and reach people. It has to be said that this participatory and process driven approach to national planning is definitely in line with the recommendations and requirements of the CCD. According to UNDP observations and evaluations it was clearly a two-way process. "While communicating information and raising awareness down to the village level, the participants also listened to the people, finding ways to convey their priorities to planners and policy-makers in the capital." 39 UNDP concluded that the process was very valuable in terms of creating a support base for future policies and also because of the contributions to the content. The president of the CONAGESE formulated it this way: "The whole population has taken ownership of the convention. It doesn't just belong to educated people in Ouagadougou. It belongs to everybody." ${ }^{40}$ As an additional indicator of the success of the process, it is worth noting that multi-stakeholder processes are planned on a two year basis in support of the implementation of the NAP. In addition, there seems to be a serious effort to establish strong links through future participatory processes to the National Environmental Action Plan as well.

iii. Local Knowledge Discourse: The NAP mentions several times that local governments and committees should include local groups and make use of the specific knowledge they have about desertification issues. No further policy steps have been announced to improve this aspect of the Desertification Convention, making it the most poorly developed part of the plan. The idea seems to be that the participation of farmers' groups during the process of participatory planning (see previous point) will solve the issue. Experiences elsewhere with the intro-

38. UNDP 2000, 35.

39. UNDP 2000.

40. UNDP 2000. 
duction of local knowledge in policy processes suggest that this is rather naïve. ${ }^{41}$ The process requires specific methodologies and dynamics, which cannot be provided by representative consultative bodies such as the farmers' groups, which usually operate at the national level and in specific institutional settings. More dynamic, interactive and locally embedded processes are needed.

The idealized image that exists in some circles regarding local or indigenous knowledge needs to be treated with caution or even amended. The processes taking place in Burkina Faso illustrate that, although farmers and other local groups do have specific and valuable knowledge about local dynamics, they lack basic knowledge of linkages between agricultural practices and desertification, of irrigation techniques, of grazing and animal husbandry practices, and so on. The following excerpts from field visit reports illustrate this point: ${ }^{42}$

For example, there was no linkage in people's minds between planting trees and improving agricultural production, even though agriculture is the basis of our economy.

People didn't understand that planting trees would protect and improve the soil. They thought it was just for firewood. So tree-planting campaigns didn't produce the desired results: to combat desertification through sustainable development.

This is not to suggest that local knowledge it is not a useful, even crucial, addition to scientific knowledge, or that it doesn't play an important role in the dynamics at the local level in terms of involvement and ownership of policies to combat desertification. It is necessary, however, to guard against a romantic view of the African farmer with his or her century old knowledge of the land versus the alien rational scientist with disconnected views of the problem.

In summary, the NAP has to a certain extent incorporated the three policy discourses described in section two. A translation of these discourses into pragmatic policy approaches has occurred, though with differing intensity and success, the participatory discourse having been most thoroughly adopted and the local knowledge discourse least. The next section discusses how much of an influence this has had on local dynamics in Ouahigouya in the Yatenga province.

c. Ouahigouya in the Yatenga Province: Local Policy Initiatives; Endogenous and Exogenous Actors and Priorities

Ouahigouya is the most important town in the Yatenga region, serving as its provincial, departmental and municipal center. It also houses several devolved state services, such as health services, education, public works, communication, and natural resources. Ouahigouya has about 60000 inhabitants, which makes 
it the fourth largest town in Burkina Faso, after Ouagadougou, Bobo Dioulasso and Koudougou. The town is in essence an urbanized village, rather than a town in the strict meaning of the term. The annual population growth rate in the town is $3.6 \%$ compared to $0.8 \%$ for the Yatenga province. ${ }^{43}$ This reflects the pull that the town has for people in the region. However, since people of the town are extremely poor by most standards, they, in turn are attracted to the capital Ougadougou.

i. Natural Resource Problems and Desertification: The Yatenga region, in the Northern part of Burkina Faso and along the border with Mali, is situated on the edge of the Sahellian zone. Precipitation is insufficient and, more importantly, too irregular to ensure a stable basis for agriculture. Since the 1974 and 1983 droughts, the water level in the underlying aquifer has dropped dramatically. Water shortage is the most pressing problem for agriculture, which is by any standard difficult and uncertain. Despite such unfavorable conditions, $72 \%$ of the population depends on agriculture as its sole economic activity. Most activity is located near the scarce water puddles. The lack of water is hence a very serious economic (and social) problem for the local population. The need for more wells, drilling holes, canals, and water treatment is high. ${ }^{44}$

The vegetation consists of trees and bush savanna, which has been under severe stress from climatic conditions and intensive human use (agriculture, animal husbandry, fire wood collection). Pressing issues are topsoil degradation and deforestation (meaning the cutting of the scarce trees in the region), which together can be labeled as a serious process of desertification. Wood is and remains the main source of energy in this deforested region, however. Intensive reforestation is, therefore, deemed necessary to fight desertification effectively.

ii. Management of Natural Resources at the Community Level: In 1990, the Burkinabé government engaged in a project on medium sized towns (le projet des dix villes moyennes) to support these towns in their socio-economic development. A key issue in this socio-economic development was the improvement of the natural resource situation. The goal was to counter the exodus towards the two large cities of the country, Ouagadougou and Bobo-Dioulasso. The municipality is (in tandem with the national government) politically and formally the first actor with responsibility to fight the problems described above. But in addition to the municipal and state dynamics, there is a strong dynamic of local action initiated by several international NGOs, endogenous associations, local groups and the local population at large. These initiatives, based largely on local organizations and foreign NGOs, are playing an important role in natural resource management of both the city and the region. Several external partners were involved in support of the national policy, providing mostly financial sup-

43. Boissard 1996; and Valkenborg 2000.

44. Boissard 1996, 15-16. 
port and exogenous capacity: Official Development Agencies, NGOs and international governmental development agencies. The Swiss ODA agency, BUCO, chose Ouahigouya as a pilot project city. The involvement of BUCO had a significant impact on the city and on local development and natural resource dynamics. ${ }^{45}$ It is fair to say that, without these external actors there would be, in fact, initially no serious natural resource or more general development policy in the city. The municipality has limited financial means, little capacity, and is operating what could be described as an institutional vacuum given the uncompleted process of deconcentration and decentralization of state agencies.

In the field of actions in connection with desertification, environmental protection and reforestation a few local organizations are active and are taking the lead (in tandem with foreign NGOs): the Red Cross, Kogl-Weogo and ECLA. The emphasis is on three issues: techniques to prevent topsoil losses, reforestation through intelligent and locally adapted tree planting campaigns, and general environmental awareness training. The environmental action taken by the municipality is embedded in the national campaign " 8000 villages- 8000 forests." The results of these activities are positive considering the vast scale and the limited means and resources of the actors. They are prominent as the only initiatives in the city. Until recently, however, they were considered rather marginal and insignificant compared to the magnitude of the problems, in terms of being effective measures in the fight against the desert formation process. However, it is worth mentioning that the most recent scientific data on desertification in the region gives a more differentiated view. In the Northern Part of Burkina Faso, including the Yatenga Province, "areas lost to the Sahara desert during decades of drought are turning green again ... Twenty years ago, severe droughts turned much of Northern Burkina Faso into a desert. But satellite surveys have shown that vegetation is returning to the country." 46 Although the improvements are attributed mostly to shifting weather patterns, researchers have also linked them to relatively minor changes in agricultural practices such as "apply[ing] some of the soil and water conservation practices more intensively [and] erect[ing] stone and earth walls to keep the soil from washing off the land in the occasional heavy downpours." 47 These changes are linked to awareness campaigns and local activities in support of the CCD's goals as they have been formulated in the NAP. Researchers have come to the conclusion that "while overall improvements have been steady, dramatic progress has been made in particular villages and areas, particularly those where donor agencies have invested consistently [in support of] soil and water conservation." 48

45. In the field of household waste collection and sanitation for example, two local organizations are active. First, Steenbok, which is supported by the Swiss Cooperation, and is concentrating on household waste collection. It employs 27 people and 5 chariots, 5 donkeys and works with 200 trash bins. Also supported by the Swiss is ECLA (être comme les autres), which operates 200 trash bins and employs 60 handicapped people in sanitation activities (ECLA 1996, internal management document).

46. New Scientist 2002.

47. Pearce 2001.

48. New Scientist 2002. 
iii. Local Natural Resource Management Initiatives in Ouahigouya: A general observation is that the NAP and certain constitutive institutional elements, such as the national decentralization, are still in their infancy, and it shows. The impact of the devolution on municipalities has been more institutional than in actual functioning of policy-making processes. Decentralization has not yet been accompanied by an adequate transfer of financial and other resources and of relevant know-how. The city is left with more responsibilities, but few resources to perform the tasks and meet the expectations formulated in the NAP. The municipality has relied for the financial aspects of its natural resource and development activities partly on national but mainly on Swiss financing. The financial input of the municipality through its own tax generation is limited, compared with the input from the Swiss Cooperation and Ouahigouya's Swiss sister city of Chambery. A significant part of the municipal development and natural resource activities is exclusively funded by external partners. This is far from optimal if one takes the decentralization discourse seriously. Independent local management is impossible under these circumstances. Moreover, in line with the Swiss ODA philosophy, and with the principles of autonomization through decentralization, the municipality's activities will have to be financed through local revenue generation in the near future. The limited financial capacity of the local population, and the low institutional capacity to collect taxes are significant obstacles.

The failings of the central and municipal government have left the initiative to local groups and external actors to get involved in the dynamics of community development, including the management of the scarce natural resources such as water, land and wood. In general these initiatives have been fairly effective, although limited in scale. A number of important problems persist, however. These private initiatives are not coordinating the activities very well. Each NGO or association seems to be catering to its own public, based on its own approach and sometimes based on locally relevant divisions within the population. ${ }^{49}$ The same is true for the co-ordination between the municipal government and the local initiatives.

Field research suggests that one of the crucial problems is the serious mistrust of political and bureaucratic powers both at the national and the local level. There are serious tensions (mostly latent) between local groups and the municipality. Some locally elected politicians are designing policies without any regard for the local dynamics and the work performed by local organizations. Strengthened by their new legitimacy of being "elected officials" they try to by-pass local groups and attempt to establish privileged relationships with external actors who generally have larger financial resources. In terms of participatory policy-making this sort of unfriendly relationship between the local policy-makers and the NGOs and associations is rather far removed from the official participatory local management discourse. A well-organized local consultation structure could help solve this problem.

49. Valkenborg 2000. 
The fact remains that, regardless of the strong local dynamics and the enabling national legislation, the level of development of relevant local policies for the protection of natural resources remains extremely low and hence the effect of the steps taken remains marginal. A closer alignment of the scarce resources and policy with the participation and decentralization discourses is essential if aspirations of contributing to desertification goals are to be realized.

The fact that the Swiss are supporting both the municipality and private actors is indicative of the following problem: ODA by definition has to operate through official institutions, but often resorts to others (local organizations, NGOs) because of their better access to scarce local resources. Decentralized state services such as the Direction Régional de l'Eau du Nord, the Direction Provinciale de la Santé and the Centre Hospitalier Régional of Ouhigouya are involved in projects, but generally lack the means to play a decisive role. In addition, they seem to lack the capacity to tap into the social networks (social capital), which often seems to be the most relevant and available resource in areas that are deprived.

The most important observation is that official initiatives as well as private initiatives are largely financed through external actors, which perpetuates structural positions of dependence. On the other hand, a lack of capacity (competence, institutional support, know-how and financial resources) is striking at all levels. These problems can for the moment only be solved through more external involvement.

With regards to the local knowledge discourse two observations can be made. During the national information and consultation round mentioned above Yatenga and Ouhigouya have obviously been included in the process. Given the location in the Sahellian zone the region has been rather prominent during that process. Through this process local knowledge has been absorbed in the broader process. The current dynamics incorporate local knowledge in a more piecemeal fashion. Organizations such as ECLA are strongly rooted in local networks and integrate local social, economic and natural resource knowledge in their functioning. The same can be said of other local structures that have been instrumental in community programs involving farmers. On the other hand, there does not appear to have been any serious attempt by the official local policy-makers to involve local knowledge in any relevant or innovative ways.

\section{Conclusion}

The Desertification Convention contains a number of innovative elements, which are generally considered to have both instrumentally and normatively positive influences on the outcome of the policy process to combat desertification. I have emphasized three discourses that are strongly present in the convention texts, namely the participatory, the decentralization and the local knowledge discourse. The inclusion of these elements can be seen as a response to, or a translation of, the policy recommendations that form the basis of sustain- 
able development as it has been institutionalized during and after the Rio conference. In that sense the CCD can be considered as a prime example of a new type of international environmental convention or regime. The challenge of translating these policy discourses into concrete action plans lies mainly with national governments, which draft National Action Plans that are (ideally) aligned with national commitments to development and broader environmental goals.

At the national level in Burkina Faso, the three discourses have been included in the National Action Plan, and partially translated into national legislation and in a decentralization process. Yet the NAP lacks more concrete steps and also clear goals and timing, thus making it a fairly empty box or a declaration of intentions. A central element in the NAP is undoubtedly the expressed need for improved management at the local level. The decentralization process, in combination with the deconcentration of a number of state bureaucracies is an essential response to these needs. However, without serious capacity building and substantial transfers of financial resources to the local level, the newly elected local officials seem to be more in "power" positions than in "policy" positions. Moreover, the fact that the deconcentrated state services are not very well coordinated with the decentralized governments is not helping either. This newly created policy vacuum has left local initiatives as the main source for community involvement in natural resource management, including the fight against desertification. Support generally comes from external sources, i.e. ODA and NGOs.

Field research in the Yatenga Province and in the city of Ouahigouya has illustrated the dynamics of the CCD and the NAP at the local level. It suggests that these dynamics are far removed from the considerable effort needed to really re-orient and integrate these elements as the core issues in innovative policy planning processes. A partial evaluation of the effects demonstrates that the results of anti-desertification activities are visible, but limited. The decentralization, participation and local knowledge discourses are marginally present in the policy discourse that is used by local policy-makers. Local and international NGOs have (typically) caught on much faster, or, more often, have themselves been using these discourses for some time and have incorporated them into their practices with variable success.

In conclusion, the CCD undeniably has an impact at the national level of policy-making. It has provided support for decentralization, for more participatory processes of policy-making and for the inclusion of local knowledge in the policy process. The NAP of Burkina Faso clearly demonstrates this. At the local level the CCD's impact is less clear. Decentralized and participatory policymaking are new elements and take place in a context of dependency on exogenous funding and organization. Further research into local dynamics that explicitly establish a link with the CCD and further comparative analysis of NAPs of different countries is needed to provide more empirical evidence. As yet, little evidence of this kind is available. 


\section{References}

Bachus, Kris, and Hans Bruyninckx. 2001. Duurzame ontwikkeling : beleidsconcept en kader voor maatschappelijke participatie. Brussels: DWTC.

Boissard, Laurent. 1996. Diagnostic socio-économique de la ville de Ouahigouya (province du Yatenga, Burkina Faso). Institut de géographie de l'Université de Neuchâtel, La collection "Géoregards - Cahiers de l'Institut de Géographie.

Burkina Faso Government. 1999. National Action Plan (Programme d'Action National de Lutte contre la Desertification). Document prepared for the UNCCD secretariat.

Caldwell, Lynton. 1990. International Environmental Policy: Emergence and Dimensions. Durham, NC: Duke University Press.

Chasek, Pamela. 1997. The Convention to Combat Desertification: Lessons learned for Sustainable Development. Journal of Environment and Development 6 (2): 147-169.

Chasek, Pamela S., and Elisabeth Corell. 2002. Addressing Desertification at the International Level: The Institutional System. In Global Desertification: Do Humans Cause Deserts?, edited by J.F. Reynolds and D.M. Stafford Smith, 275-294. Dahlem University Press.

Corell, Elisabeth. 1999. The Negotiable Desert: Expert Knowledge in the Negotiations of the Convention to Combat Desertification. Linköping: Department of Water and Environmental Studies, Linköping University.

Corell, Elisabeth, and Michele M. Betsill. 2001. A Comparative Look at NGO Influence in International Environmental Negotiations: Desertification and Climate Change. Global Environmental Politics 1 (4): 86-107.

Defourny, Jacques, Patrick Develtere, and Bénédicte Fonteneau. 1999. Sociale economie in Noord en Zuid : realiteit en beleid. Leuven/Apeldoorn: Garant.

Donnelly-Roark, Paula, Karim Ouedraogo, and Xiao Ye. 2001. Can Local Institutions Reduce Poverty: Rural Decentralization in Burkina Faso. Environment and Social Development Unit: Africa Region.

Fonteneau, Bénédicte. 2000. L'émergence de Pratiques d'économie Sociale en Matiere de Financement de la Santé au Burkina Faso. Brussels: Vlaamse Interuniversitaire Raad.

Grindle, Merilee, and John W. Thomas. 1991. Public Choices and Policy Change: The Political Economy of Reform in Developing Countries. Baltimore, MD: The Johns Hopkins University Press.

Guèye, Bara. 1999 Whither Participation? Experiences from Francophone West Africa. London: International Institute for Environment and Development.

Haas, Peter. 1992. Epistemic Communities and International Policy Coordination. International Organization 46 (1): 1-35.

Haas, Peter, Robert Keohane, and Marc Levy, eds. 1993. Institutions for the Earth: Sources of Effective International Environmental Protection. Cambridge, MA: MIT Press.

Hemmati, Minu. 2002. Multi-stakeholder Processes for Governance and Sustainability: Beyond Deadlock and Conflict. London: Earthscan Publications Ltd.

Hurrell, Andrew, and Benedict Kingsbury, eds. 1992. The International Politics of the Environment. Oxford: Clarendon Press.

IDEA. 1998. La Démocratie au Burkina Faso. International Institute for Democracy and Electoral Assistance.

Inspectie Ontwikkelingssamenwerking en Beleidsevaluatie. 2001. Onderzoek naar de samenwerking tussen Mali en Nederland 1994-1998. Den Haag.

Litfin, Karen. 1994. Ozone Discourses: Science and Politics in Global Environmental Cooperation. New York: Columbia University Press. 
Long, Carolyn. 2001. Participation of the Poor in Development Initiatives. London: Earthscan Publications Ltd.

Migdal, Joel. 1988. Strong Societies and Weak States: State-Society Relations and State Capabilities in the Third World. Princeton, NJ: Princeton University Press.

Migdal, Joel, Atul Kohli, and Vivienne Shue. 1994. State Power and Social Forces: Domination and Transformation in the Third World. Cambridge: Cambridge University Press.

Ministere de l'Environnement et de l'Eau, Secretariat permanent du Conseil National pour la Gestion de l'Environnement, Burkina Faso. 1999. Rapport sur la mise en oeuvre de la convention des Nations Unies sur la Lutte Contre la Desertification au Burkina Faso. Ouagadougou: Burkina Faso.

Ministere de l'Environnement et de l'Eau, Secretariat permanent du Conseil National pour la Gestion de l'Environnement, Burkina Faso. 2002. Deuxieme Rapport National sur la mise en oeuvre de la convention des Nations Unies sur la Lutte Contre la Desertification au Burkina Faso. Ouagadougou: Burkina Faso.

New Scientist. 2002. "Africa's Deserts are in Spectacular Retreat," February 18.

Pearce, Fred. 2001. Farming the Desert Margins. In Population and Environment Issues. AAAS Atlas of Population and Environment. Washington, D.C.: American Association for the Advancement of Science.

Sokona, Youba, Emmanuel Seck, and Masse Lo. 2000. Report on the Consideration of Local Knowledge by the Action Programmes, Networks and Mechanisms set up by the CCD Secretariat to Promote Programmes Combatting Desertification on the Regional and National Scales. Dakar, Senegal. Document prepared for the CCD secretariat.

Savadogo, K., T. Reardon, and K. Pietola. 1998. Adoption of Improved Land-use Technologies to Increase Food Security in Burkina Faso. Agricultural Systems, October 1998 Issue.

UNCCD. 1994. United Nations Convention to Combat Desertification in Countries Experiencing Serious Drought and/or Desertification, Particularly in Africa. Text of the Convention. Secretariat.

. 1999. Implementation of the Convention: Review of Reports on Implementation of Affected African Country Parties, including on the Participatory Process and the Experiences Gained and Results Achieved in the Preparation and Implementation of National Action Plans. Document prepared for the $3^{\text {rd }}$ COP, Recife.

UNDP. 2000. Building Human and Institutional Capacity for Sustainable Development. Capacity 21 Programme, annual report.

Valkenborg, An. 2000. Initiatives for Sustainable Urban Development in Burkina Faso and South Africa. Leuven: HIVA, KUL.

World Commission on Environment and Development (WCED). 1987. Our Common Future. Oxford: Oxford University Press.

Young, Oran, ed. 2000. Global Governance: Drawing Insights from Environmental Experience. Cambridge, MA: MIT Press. 
This article has been cited by:

1. Lindsay C. Stringer, Mark S. Reed, Andrew J. Dougill, Mary K. Seely, Martin Rokitzki. 2007. Implementing the UNCCD: Participatory challenges. Natural Resources Forum 31:3, 198-211. [CrossRef]

2. Steffen Bauer . 2006. Does Bureaucracy Really Matter? The Authority of Intergovernmental Treaty Secretariats in Global Environmental PoliticsDoes Bureaucracy Really Matter? The Authority of Intergovernmental Treaty Secretariats in Global Environmental Politics. Global Environmental Politics 6:1, 23-49. [Abstract] [PDF] [PDF Plus] 